\title{
KONTRIBUSI USMAN JANATIN DALAM KONFRONTASI INDONESIA-MALAYSIA, 1962-1966
}

\author{
Arif Saefudin ${ }^{1}$ \\ ${ }^{a}$ Mahasiswa Program Studi Pendidikan Sejarah FKIP-Universitas Sebelas Maret (UNS) \\ Jalan Ir. Sutami 36 A, Surakarta, 57126
}

\begin{abstract}
ABSTRAK
Tujuan dalam penelitian ini mencakup beberapa pertanyaan penelitian yang harus dijawab, yaitu menjelaskan biografi singkat Usman Janatin (2) konfrontasi antara Indonesia-Malaysia; (3) dan kontribusi Usman Janatin dalam konfrontasi. Metode dalam penulisan sejarah ini menggunakan metode peneltian sejarah. Menurut Kuntowijoyo, peneltian yang dilakukan ketika menggunakan metode sejarah ada 5 tahap, yaitu (1) pemilihan topik; (2) heuristik atau pengumpulan sumber; (3) verifikasi atau kritik sejarah, keabsahan sumber; (4) interpretasi; dan (5) historiografi atau penulisan. Hasil dalam penelitian ini adalah kehidupan Janatin dari kecil hingga menjadi anggota Korps Komando Angkatan Laut (KKOAL). Konfrontasi Indonesia dan Malaysia diakibatkan karena rencana Inggris yang akan membentuk Sebuah Gabungan wilayah jajahanya menjadi Federasi Malaysia. Presiden Sukarno menolak keras pembentukan Federasi Malaysia yang dianggap sebagai proyek Neo-kolonialisme oleh Inggris. Hal ini membuat Presiden Sukarno mengeluarkan Dwi Komando Rakyat (Dwikora). Janatin bersama rekanrekannya berhasil melakukan infiltrasi dan sabotase ke MacDonaal House di Singapura, yang saat itu masih menjadi bagian dari Federasi Malaysia. Namun, aksi Janatin terhenti ketika ia tertangkap. Dengan proses yang panjang, akhirnya Janatin divonis hukuman mati dengna cara digantung. Setelah eksekusi berlangsung, Presiden Soeharto menetapkan Janatin sebagai Pahlawan Nasional dengan SK Presiden RI No. 050/TK/1968 tertanggal 17 Oktober 1968.
\end{abstract}

\section{Kata Kunci: Usman Janatin, Konfrontasi Indonesia-Malaysia}

\begin{abstract}
The aims of this study include several research questions to be answered, namely explaining the brief biography of Usman Janatin (2) the confrontation between Indonesia-Malaysia; (3) and Usman Janatin's contribution in the confrontation. Methods in writing this history using historical research methods. According Kuntowijoyo, research conducted when using the method of history there are 5 stages, namely (1) selection of topics; (2) heuristics or source collection; (3) historical verification or criticism, source validity; (4) interpretation; and (5) historiography or writing. The results in this study were Janatin's life from small to becoming a member of the Naval Command Corps (KKO-AL). The confrontation of Indonesia and Malaysia was due to the British plan which would form a Jabungan Joint Territory into a Malaysian Federation. President Sukarno strongly rejected the formation of the Federation of Malaysia which was considered a project of Neo-colonialism by the British. This prompted President Sukarno to issue a Dwi Komando Rakyat (Dwikora). Janatin and his colleagues successfully infiltrated and sabotaged MacDonaal House in Singapore, which was then part of the Malaysian Federation. However, Janatin action stalled when he was caught. With a long process, Janatin finally sentenced to death by hanging. After the execution took place, President Soeharto established Janatin as a National Hero by Presidential Decree No. RI. 050 /TK/1968 dated 17 October 1968.
\end{abstract}

Keywords: Usman Janatin, Confrontation Indonesia-Malaysia

\footnotetext{
${ }^{1}$ Penulis Koresponden

E-mail address: arifsae.com@gmail.com

doi: http://dx.doi.org/10.25157/ja.v4i2.903
}

Copyright@2017 Jurnal Artefak e-ISSN: 2580-0027

Halaman | 95 


\section{PENDAHULUAN}

Konstelasi politik dunia yang terjadi pada pada era tahun 1960-an memang tidak bisa dilepaskan dengan persaingan antara dua blok adidaya. Blok Barat representasi Amerika Serikat (AS) dengan Liberal Kapitalis-nya dan Blok Timur dengan Uni Soviet Rusia (USSR) sebagai komandan Sosialis Komunis. Perang Dingin atau Cold War, istilah yang sering kita dengar ini menggambarkan rivalitas dua negara adidaya yang "menjual" ideologinya ke wilayahwilayah negara lain didunia. ${ }^{2}$ Kondisi ini, membuat negara didunia dirundung kekhawatiran andai Perang Dingin ini pecah menjadi "Perang Panas". Perebutan supremasi antar dua negara adidaya ini terasa hingga beberapa kawasan Asia Tenggara, termasuk Indonesia.

Sejalan dengan hal tersebut, kondisi di Indonesia pada tahun itu menunjukan adanya perjuangan dalam usaha merebut Irian Barat dari Belanda. Hingga akhirnya pada tanggal 1 Oktober 1962 pihak Belanda menyerahkan Irian Barat kepada pemerintahan sementara PBB, yang kemudian akan menyerahkanya kepada pihak Indonesia pada 1 Mei 1963. Ketika masalah Irian Barat mendapatkan titik terang, disisi lain, masalah luar negeri yang lain muncul. Permasalahan ini bermula dari rencana pembentukan "Federasi Malaysia". Pembentukan Federasi Malaysia ini didasari dari persamaan masalah yang dialami dari negara Malaya, Singapura dan Inggris. Malaya cemas dengan penduduk Tionghoa dan implikasinya terhadap rasial dari penggabungan dengan Singapura, pihak Singapura menginginkan sebuah kemerdekaan yang penuh, serta pihak Inggris menginginkan solusi terhadap masa depan wilayah-wilayah jajahannya di Pulau Kalimantan, seperti Sabah, Brunei dan Sarawak. $^{3}$

Persepsi Presiden Sukarno terhadap pembentukan Federasi Malaysia ini lain, menurutnya, pembentukan ini merupakan rekayasa dari Blok Barat untuk menancapkan kekuasaannya dikawasan Asia, khusunya Asia Tenggara. Pembentukan Federasi Malaysia ini akan mengepung Indonesia dari kekuatan neokolonialisme dan neo-imperialis. ${ }^{4}$ Hubungan Indonesia dengan Malaysia yang tidak berjalan harmonis. Hal ini antara lain disebabkan oleh kehadiran dan campur tangan Inggris. Presiden Sukarno menganggap Malaysia tidak sepunuhnya sudah merdeka atau hanya purapura merdeka karena tidak pernah merasakan namanya pahit-getir sebuah revolusi fisik yang pernah dialami Indonesia. Daniel Dhakidae bahkan menyebut bahwa Malaysia dalam memperoleh kemerdekaanya diberikan karena "Merdeka Hadiah", berbeda dengan Indonesia yang "Merdeka Darah". 5

Berbagai usaha diplomasi dilakukan untuk menyelesaikan ketegangan antara dua negara tetangga ini. Salah satunya, pertemuan antara Presiden Sukarno dan Perdana Menteri Malaya, Tengku Abdul Rachman yang dilakukan di Tokyo pada tanggal 1 Juni 1963. Hasil dari pertemuan ini sedikit meredakan ketegangan dua negara. Namun, ketika proses perundingan yang hampir mencapai titik temu, PM Tengku Abdul Rachman menandatangai dokumen persetujuan dengan Inggris di London mengenai deklarasi Negara Federasi Malaysia yang akan dilaksanakan pada tanggal 31 Agustus 1963. Realitas yang ada menunjukan bahwa penandatanganan ini merupakan sebuah penghinaan besar bagi kedaulatan Indonesia, seperti yang dikatakan Presiden Sukarno.

Menanggapi hal tersebut, Presiden Sukano kembali menghidupkan semangat revolusi "Indonesia Raya", dengan menyatakan negara baru itu merupakan boneka nekolim, (neo-kolonialimse dan neo-imperialisme). Langkah berikutnya adalah membangkitkan semangat "Konfrontasi". Istilah ini pertama kali diungkapkan oleh Soebandrio pada Januari 1963 setelah pasukan Malaya dan Inggris menghancurkan pembrontakan di Kasultanan Brunei di Kalimantan Utara. ${ }^{6}$ Kemudian setelah

\footnotetext{
2 Tanto Sukardi, Perang Dingin: Episode Sejarah Barat dalam Perspektif Konflik Ideologi, (Yogyakarta: Pustaka Pelajar, 2011), hlm. 2-3.

${ }^{3}$ Shukri Shuib, et al. "The Implications of Cold War on Malaysia State Building Process". Jurnal Asian Culture and History, Vol 1, No. 2, July 2009, hlm 89-98.

${ }^{4}$ Roso Daras. Total Bung Karno, Serpihan Sejarah yang Tercecer (cetakan ke-empat). (Depok: Penerbit Imania, 2013), hlm. 153.

${ }^{5}$ Daniel Dhakidae. "Hubungan Cinta-Benci antara Indonesia dan Malaysia”. Majalah Prisma Vol. 28, No. 2, September 2009, hal 50-53.

${ }^{6}$ Robert Cribb dan Audrey Kahin, Historical Dictionary of Indonesia. (Toronto: The Scarecrow Press, Inc. 2004), hlm. 248.
} 
itu, muncul sebuah slogan baru untuk memanaskan semangan konfrontasi itu, yaitu Ganyang Malaysia.

Realisasi dari fenomena tersebut ditunjukkan dalam bentuk demonstrasi yang dilakukan setiap minggu untuk membangkitkan semangat Anti-Inggris dengan slogan Ganyang Malaysia. Langkah selanjutnya, bisnis-bisnis Inggris dan bisnis ekonomi Persmakmuran lainnya diambil alih selama tahun 1964-1965. ${ }^{7}$ Pemerintah Indonesia juga menggabungkan strategi politik konfrontasi dengan diplomasi. Taktik yang sama dilakukan ketika Presiden Sukarno mengambil alih Irian Barat. Menurut Frederick P. Bunnel kebijakan politik ini dilukiskan sebagai "confrontation diplomacy", suatu campuran manuver yang bersifat berani, cerdik-licik dan tidak dapat diduga. ${ }^{8}$

Untuk mendukung kebijakan Ganyang Malaysia ini, dilancarkan berbagai konfrontasi oleh ABRI (Angkatan Bersenjata Republik Indonesia) dan sukarelawan serta sebagian dari masyarakat luas berdasarkan seruan Dwi Komando Rakyat (Dwokora), yang berisi tentang mempertinggi ketahanan Revolusi Indonesia dan membantu perjuangan rakyat Kalimantan Utara. ${ }^{9}$ Salah satu sukarelawan dari kalangan ABRI yang ikut dalam operasi itu adalah Usman bin Haji Muhammad Ali alias Usman Janatin.

Usman Janatin lahir di Purbalingga, sebuah Kabupaten yang ada di Provinsi Jawa Tengah. Kabupaten yang memiliki luas 77.764 hektare ini memiliki pahlawan-pahlawan terbaik bangsa dari kalangan militer, salah satunya Panglima Besar Jenderal Soedirman, tokoh yang pernah menjadi "sentral" militer pada awal kemerdekaan. Maka tidak heran, kabupaten ini mendapat julukan "Kota Perwira". Sebuah julukan untuk menghormati perwira-perwira yang sudah membela martabat bangsa.

Selain Soedirman, Purbalingga juga mempunyai putera terbaik dari kalangan "perwira" lainnya, yaitu Usman Janatin. Berdasarkan semangat Dwikora, Usman Janatin dan rekan-rekannya mendapatkan tugas untuk

\footnotetext{
${ }^{7}$ Adrian Vickers, A History of Modern Indonesia. (New York. Cambridge University Press, 2005), hlm. 228-229.

8 Yahya A. Muhaimin, Perkembangan Militer dalam Politik di Indonesia 1945-1966 (certakan ke-tiga). Yogyakarta: Gadjah Mada University Press, 2005), hlm. 156.

9 Steven Farram, "Ganyang! Indonesian Populer Songs from the Confrontation Era, 1963-1966”. Jurnal Bijdragen
}

melakukan penyusupan ke Singapura. Dalam tugas ini, Usman Janatin sebagai pimpinan atas rekan-rekannya, Harun bin Haji Mahdar dan Gani bin Aroep. Surat tugas yang bernomor SP. KKO No. 05/Sp/KKO/64 dan Spd KOTI No. 288/KOTI/8/64, tertanggal 27 Agustus 1964 ini sebagai dasar mereka untuk melakukan pemboman terhadap tempat di Singapura. ${ }^{10}$

Tokoh yang patut mendapat julukan patriot bangsa ini mau menjadi sukarlawan meski nyawa taruhanya. Sikap patriot ini merupakan semangat cinta tanah air atau sikap seseorang yang rela mengorbankan jiwa maupun raganya untuk negara. Sikap rela berkorban ini dimaksudkan untuk membela bangsa dan negara dari berbagai gangguan, baik itu dari dalam negeri maupun luar negeri. Sikap patriotisme ini juga melekat pada sikap nasionalisme. ${ }^{11}$ Artinya, ketika seseorang sudah memiliki sikap nasionalisme maka secara otomatis akan memiliki sikap patriotisme. Beberapa pertanyaan penelitian dalam penulisan ini adalah, bagaimana biografi singkat Usman Janatin? (2) konfrontasi antara IndonesiaMalaysia; (3) dan kontribusi Usman Janatin dalam konfrontasi.

\section{METODE PENELITIAN}

Metode dalam penulisan sejarah ini menggunakan metode peneltian sejarah. Menurut Kuntowijoyo, ${ }^{12}$ peneltian yang dilakukan ketika menggunakan metode sejarah ada 5 tahap, yaitu (1) pemilihan topik; (2) heuristik atau pengumpulan sumber; (3) verifikasi atau kritik sejarah, keabsahan sumber; (4) interpretasi; dan (5) historiografi atau penulisan.

Topik dalam penulisan ini mengacu pada sosok Usman Janatin dan perannya dalam konfrontasi antara Indonesia-Malaysia. Setelah memilih topik, peneliti harus mengumpulkan sumber-sumber atau dokumen-dokumen mengenai topik penelitian. Sejarawan bekerja berdasarkan berbagai dokumen, karena

Tot De Tall-, land- En Volkenkunde 170 (2014) 1-24. Hlm 8

${ }^{10}$ Herman Mujirun, Sekilas Kenangan 2 (dua) Pahlawan Serda KKO Usman Bin H. Ali dan Kopral KKO Harun Bin Said. (Jakarta: Yayasan Sosial Usman-Harun, 1974), hlm. 1.

${ }^{11}$ Ibid,.

12 Kuntowijoyo, Pengantar Ilmu Sejarah (edisi ke-tiga). (Yogyakarta: Yayasan Banteng Budaya, 1999), hlm. 88-89. 
dokumen merupakan jejak pikiran dan perbuatan yang telah ditinggalkan oleh orang-orang zaman dahulu. ${ }^{13}$ Begitu pentingnya dokumen dalam sejarah, maka sampai ada istilah no documen no history, tidak ada dokumen tidak akan ada sejarah.

Selain maha penting, tahap pengumpulan data atau heuristik ini merupakan tahap yang paling menyita banyak waktu. Pengumpulan pertama yang dilakukan untuk mencari dokumen yang berkaitan dengan tema/topik yang akan diteliti. Dalam penelitian ini, dokumen dan sekaligus peninggalan catatan yaitu berupa surat, piagam, serta rekaman wawancara, dokumentasi dan lainnya. Sumber catatan-catatan dan dokumentasi bisa ditemui didalam museum Usman Janatin, berupa surat-surat, piagam, tanda jasa, dan catatan-catatan yang lain. Selain itu, wawancara dilakukan kepada saudarasaudara Usman Janatin yang sebagain besar masih hidup. Ada teman-teman kecilnya juga yang sebagian besar masih tinggal di Purbalingga. Untuk menambah sumber data, dikumpulkan juga berbagai referensi dari bukubuku, jurnal, majalah, surat kabar yang menunjang tentang penulisan sekitar tahun 1960-an.

Setelah data terkumpul kemudian dilakukan verifikasi. Verifikasi ada dua macam, otensitas atau keaslian sumber (kritik ekstern) dan kredibilitas atau kebisaan dipercayai (kritik intern). ${ }^{14}$ Dalam penelitian ini, kritik sumber eksternal yang dilihat dari berbagai koleksi museum Usman Janatin, apakah materi itu merupakan materi yang memang sezaman, disamping itu bisa dilihat berbagai kertas dengan jenis dan ukuran, bahan, kualitas dan lainnya. Jadi, bisa diartikan bahwa kritik eksternal merupakan kritik secara fisik dan menyesuaikan dengan anak zaman.

Selain kritik eskternal, yang harus dilakukan peneliti adalah kritik internal. Kritik internal ditujukan untuk memahami isi teks atau dokumen. Misalkan, menurut Alwi Shahab, pada era 1960-an situasi panas karena Usman dan Harun akan di makamkan di TMP Kalibata,

\footnotetext{
${ }^{13}$ CH.V Loanglois dan CH Seignobos, Introduction to the Study of Hostory, Pengantar Ilmu Sejarah (terj). (Yogyakarta: Indoliterasi, 2015), hlm. 25.

${ }^{14}$ Kuntowijoyo, op.ic, hlm. 98.

15 Alwi Shahab, "Usman-Harun dan Ekspresi Kemarahan Rakyat”. Koran Republika, 13 Februari 2014, halaman 1 dan 9.

16 Beberapa sumber menyebut tanggal lahir Janatin 22 Maret 1943. Tanggal ini peneliti temui dalam biodata
}

diperkirakan 1 Juta atau sepertiga penduduk Jakarta kala itu turun kejalan memenuhi jalanjalan yang dilewati jenazah untuk memberikan dukungan dan penghormatan terakhir. ${ }^{15}$ Pertanyaanya, apakah ada dokumentasi mengenai banyaknya iring-iringan jenazah ketika kembali dari Singapura? Kalau memang sambutan itu ada, maka bisa diakui kalau foto itu adalah kredible.

Tahap berikutnya, interpretasi. Untuk menghasilkan cerita sejarah, maka diperlukan interpretasi. Interpretasi dalam penelitian ini adalah memberikan makna pada fakta atau dokumen yang telah ditemukan. Dalam kasus konfrontasi antara Indonesia dan Malaysia, sumber tulisan memang banyak ditulis, sehingga semakin banyak data yang didapat maka akan semakin baik dan memudahkan untuk melakukan interpretasi terhadap kiprah Usman Janatin.

Langkah terakhir yaitu historiografi atau penulisan sejarah. Pada tahap penulisan ini, peneliti menyajikan laporan hasil penelitian yang disajikan berdasarkan kaidah-kaidah yang berlaku dalam Ilmu Sejarah.

\section{HASIL PENELITIAN DAN PEMBAHASAN}

\section{Siapa Usman Janatin?}

Usman Janatin terlahir dengan nama Janatin. Ia lahir tepat pada hari Rabu Pon tanggal 18 Maret $1943^{16}$ jam 10.00 pagi. Janatin lahir dari rahim Siti Rukijah, seorang ibu rumah tangga di Dusun Tawangsari, yang masuk kedalam wilayah administrasi Desa Jatisaba, Kecamatan Purbalingga, Kabupaten Purbalingga. Ketika dilahirkan oleh Siti Rukijah, Janatin merupakan anak ke-7. Nama-nama saudaranya dari yang paling tua hingga muda yaitu: (1) Ahmad Kusni, anggota militer; (2) Ahmad Chuneni, anggota militer; (3) Ahmad Matori, anggota militer; (4) Siti Rochajah, ibu rumah tangga; (5) Mohammad Chalimi, Pegawai Kecamatan Bobotsari; (6) Siti Rodijah, ibu rumah tangga; (7) Djanatin; dan anak terakhir (8) 
Siti Turijah, seorang ibu rumah tangga. ${ }^{17}$ Ayahnya, Haji Mochammad Ali, merupakan orang yang dihormati karena posisinya sebagai seorang kayim atau lebe. ${ }^{18}$

Sebagai seorang kayim atau lebe, pola pendidikan yang diberikan kepada anak-anaknya juga tak jauh dari sifat religiusitas agama Islam. Dunia militer nampaknya menjadi hal biasa, karena kakak sulung Janatin, Letkol Ahmad Kusni menjadi pejuang dan gugur pada pertempuran di Karang Kobar, Purbalingga. ${ }^{19}$ Saat itu, kontak senjata terjadi antara pasukan Republik dan pasukan Belanda, dengan pertempuran yang tidak seimbang, Letkol Ahmad Kusni akhirnya terkena granat yang mengakibatkan kakinya terluka sangat parah dan tak utuh lagi. Ia gugur sebagai pahlawan. ${ }^{20}$ Kejadian inilah yang menjadi inspirasi Janatin untuk ikut menjadi anggota militer.

Pendidikan formalnya dimulai saat usia Janatin memasuki 7 tahun. Ayahnya mendaftarkan Janatin kesekolah formal di Sekolah Rakyat $(\mathrm{SR})^{21}$ terdekat, yaitu SR Jatisaba. Tepatnya tahun 1951, Janatin untuk pertama kalinya memasuki pendidikannya di SR Jatisaba. Proses Janatin bersekolah di SR Jatisaba dilalui hanya selama 3 tahun. Hal ini dikarenakan keterbatasan ruangan yang ada di SR Jatisaba. SR Jatisaba hanya bisa menampung

\footnotetext{
17 Dari penuturan Siti Rodijah, selain nama diatas, ada saudaranya yang meninggal ketika masih kecil, yaitu Sopiah dan Salbiah. Diantara 10 orang saudaranya, masih ada 4 orang yang hidup hingga saat ini, yaitu Ahmad Matori, Siti Rochajah, Siti Rodijah, dan Siti Turijah [red: tahun 2017]. Dalam adat Jawa, mempunyai banyak anak akan mendapat banyak keuntungan, salah satunya semakin banyak anak akan mempunyai banyak rejeki, atau orang Jawa merasa lebih yakin akan dirinya apabila ada banyak anak, karena akan membantunya dalam segala hal. Lihat Koentjaraningrat, Kebudayaan Jawa, (Jakarta: Balai Pustaka, 1994), hlm 99-100.

${ }^{18}$ Secara tradisional, di pulau Jawa pamong desa dianggap sebagai kelompok instrumen atau perabot desa yang terdiri dari dua tingkatan yaitu desa dan dusun. Pada tataran desa, biasanya ada dua aparat desa yaitu Kepala Desa (Lurah) dan Carik. Sedangkan di tingkat dusun ada lima perangkat yaitu Kamitua/Bau, Jagabaya/Pulisi, Kebayan, dan Modim/Lebe/Kayim. Sementara itu kedudukan lebe, kyai, dan kunci adalah sebagai pelaksana harian untuk memimpin upacara-upacara adat dan kegiatan keagamaan. Lihat Imam Tholhah, Anatomi Konflik Politik di Indonesia: Belajar dari Ketegangan Politik Varian di Madukoro, (Jakarta: PT. Raja Grafindo Persada, 2001) hlm. 169-170.

19 Letkol Isdiman merupakan anak buah Jenderal Soedirman. Beliau gugur ketika terjadi pertempuran antara Indonesia dengan Belanda di Palagan, Ambarawa. Lihat Sasono dan Tri Atmo, Mengenal Purbalingga, (Jakarta: Paguyuban Arsantaka, 1993), hlm. 81-82.
}

kelas 1 hingga kelas 3 sehingga untuk melanjutkan kelas 4 sampai 6, Janatin harus pindah ke SR Bancar yang jaraknya lebih jauh lagi, yaitu sekitar $3 \mathrm{Km}$.

Setelah melalui proses pendidikan selama 6 tahun di SR, akhirnya Janatin lulus tahun 1957. Kemudian Ia melanjutkan ke jenjang pendidikan Sekolah Menengah Pertama (SMP) Bhakti Mulya. $^{22}$ Ketika memasuki akhir masa pendidikannya di SMP Bhakti Mulya pada tahun 1961, Janatin mendapatkan kabar tentang panasnya politik terkait masalah Irian Barat. Meskipun tidak mendapat restu orang tuanya, Janatin tetap mendaftar menjadi Tamtama. Pendaftaran yang dibuka adalah untuk Sekolah Calon Tamtama KKO AL (Secatamko) yang berada di Malang, Jawa Timur. ${ }^{23}$ Dengan optimis tinggi, akhirnya pada awal tahun 1962 , Janatin dinyatakan diterima menjadi anggota KKO AL, yang masuk kedalam angkatan ke-10. Setelah mengikuti serangkaian pendidikan dan pelatihan, akhirnya Janatin dinyatakan lulus pendidikan militer pada tanggal 1 Juni 1962. Janatin berhak memakai Baret Ungu KKO AL dan mendapatkan pangkat Prajurit III KKO AL. Bagi seorang anggota KKO AL, warna Baret Ungu memiliki makna kesaktian yang ampuh dan mampu memberikan pengamanan serta perlindungan. ${ }^{24}$

\footnotetext{
${ }^{20}$ Nama Letkol Ahmad Kusni saat ini dijadikan nama jalan disekitar Desa Jatisaba, tepatnya sekitar kompleks rumah keluarga Janatin. Wawancara dengan Siti Turijah, adik kandung Janatin, tanggal 28 Juli 2017 di rumahnya Desa Jatisaba Purbalingga.

21 Sekolah Rakyat (SR) digunakan untuk menampung seluruh warga Indonesia tanpa kecuali. Nama SR bukan hanya terjemahan dari Volk School dalam pengajaran kolonial yang merupaan sekolah untuk pribumi dan bukan untuk kaum bangsawan. Nama SR diganti mejadi Sekolah Dasar pada 1963 yang lebih sesuai dengan tujaun dan dasar UUP 1950, yaitu memberikan dasar-dasar pengetahuan, kecakapan dan ketangkasan lahir dan batin bagi setiap warga negara. Lihat dalam Anwar Yasin, Pembaharuan Kurikulum Sekolah Dasar, Sejak Proklamasi Kemerdekaan (Jakarta: Balai Pustaka, 1987), hlm. 71.

${ }^{22}$ Saat ini SMP Bhakti Mulya berubah menjadi SMP Borromeus yang dikelola secara profesional oleh Yayasan Santa Maria dibawah naungan Tarekat Suster-Suster Notre Dame (SND).

${ }^{23}$ Muchtaruddin Ibrahim, Usman Bin Haji Muhamad Ali alias Janatin, (Jakarta: Proyek Inventarisasi dan Dokumentasi Sejarah Nasional, 1993) hlm. 20.

${ }^{24} \mathrm{KKO}$ AL memilih warna Ungu tersebut karena dapat diandalkan kemampuanya dalam melindungi dan mengamankan Negara dan Bangsa Indonesia. Selain itu, Warna Ungu juga diilhami oleh Bunga Bougenville, yaitu bunga yang selalu gugur sebelum layu itu melambangkan pengabdian prajurit KKO AL yang selalu siap berkorban jiwa dan raga bagi keutuhan dan kejayaan NKRI. Lihat
} 
Sejak dimulainya Trikora, sejumlah 2000 sukarelawan dari pasukan-pasukan terpilih Angkatan Perang Republik Indoesia (APRI) dilatih khusus untuk terjun ke Irian Barat. Salah orang yang mengambil bagian dari pasukan itu adalah Janatin. Sebagai bagian dari APRI, Angkatan Laut Republik Indonesia (ALRI) merupakan unsur utama yang bisa menjadi unsur angkut pasukan serta logistik. Oleh karena itu, ALRI mendapatkan jatah paling besar dalam pembelian alat-alat perang. Janatin melaksanakan tugas untuk pertama kalinya di Irian Barat dengan melakukan Operasi Sadar.

$$
\text { Janatin beserta rekan-rekannya }
$$

melakukan Operasi Sadar ini untuk mengamankan hasil-hasil militer dan perundingan diplomasi. Akan tetapi yang paling utama adalah persiapan menghadapi peralihan kekuasaan di Irian Barat dari tanggan PBB ke tangan RI pada tanggal 1 Mei 1963. Operasi Sadar yang diikuti oleh Janatin berjalan dengan berbagai tantangan dan kendala. Kendalakendala ini terutama terletak pada alat-alat penghubung dengan detasemen, karena hanya menggunakan pesawat yang didrop bersama pasukan, sehingga banyak mengalami kerusakan atau hilang. Meski ada beberapa kendala, Janatin menjalani tugas di Irian Barat ini dengan rasa bangga. Cita-cita yang dulu pernah diimpikannya menjadi nyata, yaitu ikut berkontribusi memperjuangkan harkat dan martabat bangsa.

Setelah selesai melaksanakan tugas di Irian Barat, ${ }^{25}$ Janatin ditarik kembali ke kesatuannya di Surabaya. Meskipun tugas di Irian Barat telah selesai, namun tugas negara yang lain telah menanti Janatin dan prajuritprajurit KKO AL lainnya, yaitu Operasi Dwikora. Komando Dwikora dikumandangkan oleh Presiden Sukarno sebagai bentuk konfrontasi terhadap pembentukan Federasi Malaysia yang disebutnya bagian dari proyek neokolonialisme Inggris.

\footnotetext{
Majalah Marinir, "Sejarah Korps Marinir dan Emblem", edisi 144, November 2014, hlm. 4.

${ }^{25}$ Penyelesaian masalah Irian Barat diakhiri tahun 1963 terjadi pemindahan kekuasaan dari pemerintah kolonial Belanda kepada pemerintah Republik Indonesia. Sebagai bagian dari Persetujuan New York, Indonesia melaksanakan Penentuan Pendapat Rakyat (Pepera) pada tahun 1969 dan hasilnya resmi 1024 wakil-wakil orang Papua memilih bergabung dengan Indonesia. Setelah diadakannya Penentuan Pendapat Rakyat (Pepera), secara de facto dan de jure Papua Barat ini menjadi bagian dari Negara Kesatuan Republik Indonesia, menjadi propinsi ke26 dengan nama Propinsi Irian Jaya. Lihat Suko Bandiyono,
}

\section{Konfrontasi Indonesia-Malaysia}

Awalnya, pembentukan Federasi Malaysia bersumber dari usul Lord Brusscy, yang menjabat sebagai Direktur British North Borneo Company. Ia mempunyai gagasan dan ide yang disampaikan kepada pemerintahan Inggris untuk mempersatukan tanah jajahannya di Asia Tenggara dalam suatu wilayah kesatuan. Wilayah-wilayah itu adalah Borneo Utara (Sabah), Sarawak, Singapura, Brunei dan tentunya Malaya sendiri. Gagasan dari Lord Brusscy itu kemudian menarik perhatian Malcom MacDonald, seorang pejabat tinggi British High Commissionar untuk jajahan Inggris di Asia Tenggara. ${ }^{26}$

Perkembangan selanjutnya, Inggris mulai menyadari tentang masa depan wilayah jajahannya ini, dari perubahan zaman yang tak memungkinkan untuk bisa dipertahankan dalam waktu jangka panjang. Oleh karena itu, Inggris "terpaksa" memberikan kemerdekaan kepada Malaya pada 31 Agustus 1957. Tawaran kemerdekaan itupun sebenarnya tidak bisa terlepas dari kepentingan-kepentingan ekonomi di kawasan Asia Tenggara. Pemberian kemerdekaan terhadap Persekutuan Tanah Melayu tentu tidak berarti bahwa kepentingan Inggris hilang semuanya. Inggris mempunyai kerjasama dan kesepakatan dalam berbagai bidang, seperti kerjasama dalam kemajuan ekonomi, kestabilan politik dan pertahanan bersama. ${ }^{27}$

Salah satu pelopor dari pembentukan Federasi Malaya adalah PM Malaya Tengku Abdul Rahman. Ia menyampaikan, "Malaya sebagai bangsa sekarang ini tidak akan dapat berdiri sendiri. Cepat atau lambat, Malaya harus ada saling pengertian dengan Inggris dan rakyat-rakyat Singapura, Sabah, Brunei dan Sarawak". ${ }^{28}$ Bagi daerah-daerah ini, pembentukan Federasi Malaysia dimaksudkan untuk lebih mendekatkan pandangan politik dan

dkk, Mobilitas Pendududuk di Perbatasan Papua-PNG, (Jakarta: Pusat Penelitian Kependudukan Lembaga Ilmu Pengetahuan Indonesia (PPK-LIPI), 2004) hlm. 44.

26 Kusumah Hadiningrat, Sedjarah Operasi-Operasi gabungan Dalam Rangka Dwikora, (Jakarta: Departeman Pertahanan - Keamanan Pusat Sedjarah ABRI, 1971), hlm 2.

27 Mohd Noor bin Abdullah, Kemasukan Sabah dan Serawak ke dalam Persekutuan Malaysia, (Kuala Lumpur: Dewan Bahasa dan Pustaka Kementrian Pelajaran Malaysia, 1979) hlm. 30.

${ }^{28}$ Kusumah Hadiningrat, op.cit, hlm 3. 
kerjasama ekonomi. Ketimpangan ekonomi antara daerah Kalimantan Utara (Sabah, Sarawak dan Brunei) dengan daerah Melayu serta Singapura sangat mencolok. Daerah Singapura dan Malaya lebih maju sedangkan daerah Kalimantan Utara sangat jauh teringgal.

Gagasan pembentukan Federasi Malaysia tersebut ternyata mendapatkan pertentanganpertentangan dari dalam maupun luar empat daerah tersebut. Tantangan dalam negeri pada umumnya dilakukan secara legal berupa pernyataan-pernyataan anti Federasi Malaysia dan berusaha untuk mencegahnya. Hampir semua partai-partai pemerintahan menyetujui pembentukan Federasi Malaysia ini. Berbeda dengan 4 partai oposisi yang keras menolak. Diantara yang menolak adalah, The Pan Malayan Islamic Party, yang menolak pembentukan Federasi Malaysia dan mendesak agar dibatalkan persetujuan yang telah ditanda tangani, sebagai gantinya diadakan Pemilihan Umum.

Selain reaksi dari partai oposisi, protes atas pembentukan Federasi Malaysia juga datang dari 36 organisasi-organisasi buruh di Singapura yang bersepakat bahwa pembentukan ini adalah proyek neo-kolonialisme. Disamping itu, penolakan-penolakan dari rakyat Kalimantan Utara juga dilakukan. Penolakan tersebut datang ketika rakyat Kalimantan Utara tidak berhasil memperjuangkan kemerdekaannya melalui jalur hukum dan rapat-rapat raksasa. Semua perjuangan yang telah dilakukan rakyat Kalimantan Utara itu tidak diperhatikan oleh Pemerintah Inggris. Bahkan PM Tengku Abdul Rahman justru mengeluarkan Security Bill yang pada hakekatnya menentang dan mengintimidasi kemerdekaan untuk berbicara dan menulis. ${ }^{29}$

Dengan sikap penolakan seperti itu, ada kelompok-kelompok yang melakukan pembrontakan dengan senjata. Salah satunya adalah kelompok pemberontakan pimpinan Azahari yang berasal dari Partai Rakyat. Untuk mendukung perjuangan Azahari tersebut, berbagai cara dilakukan, salah satunya mengadakan kerjasama dengan Front Sosialis ketika berkunjung ke Kuala Lumpur. Termasuk juga ketika kunjungan ke Indonesia pada

\footnotetext{
${ }^{29}$ Nyoman Arsana, dkk, op.cit, hlm 20.

30 Frans. S. Fernandes, Hubungan Internasional dan Peranan Bangsa Indonesia Suatu Pendekatan Sejarah, (Jakarta: Departemen Pendidikan dan Kebudayaan Direktorat Jendral Pendidikan Tinggi Proyek Pengembangan Lembaga Pendidikan Tenaga Kependidikan, 1988) hlm. 156.
}

November 1961 yang bekerjasama dengan PKI. ${ }^{30}$ Puncaknya ketika kemarahan rakyat memuncak dan meluas hingga keadaan sulit dikendalikan, maka Dewan Legislatif Brunei yang sebagian besar anggotanya berasal dari Partai Rakyat mengadakan sidang. Hasil dari sidang itu menghasilkan mosi tidak percaya, meskipun akhirnya dibatalkan oleh pemerintah Inggris. Mosi-mosi ini dijawab oleh Council of State pada tanggal 3 Desember 1962 atas nama pemerintahan Inggris. Alasanya karena mosi tidak percaya tersebut tidak ada hubungannya dengan pemerintahan Brunei tapi menjadi urusan Inggris dan Malaya. Sebelum rakyat mendengar penolakan mosi tersebut, para wakilwakil rakyat Sabah, Sarawak dan Brunei yang menolak pembentukan Federasi Malaysia mengadakan rapat rahasia di Kalimantan Utara. Rapat rahasia itu menghasilkan keputusan untuk mendirikan dan memproklamasikan Kemerdekaan dari Negara Kesatuan Kalimantan Utara (NKKU) pada tanggal 8 Desember 1962. 31

Menurut Presiden Sukarno, Indonesia selalu berjuang untuk membela hak penentuan nasib sendiri dari semua bangsa di dunia dan revolusi yang dilakukan oleh pihak Azahari merupakan kehendak rakyat Kalimantan Utara sendiri. Rakyat Kalimantan Utara menentang berlangsungnya kolonialisme terselubung yang dilaksankan oleh Inggris dalam pembentukan persekutuan Federasi Malaysia. ${ }^{32}$ Federasi Malaysia, bagi Indonesia merupakan konsep kolonialisme yang bertentangan dengan sikap politik luar negeri Indonesia yang anti terhadap imperialisme dan kolonialisme. Presiden Sukarno menegaskan bahwa segenap pihak harus mendukung revolusi Kalimantan Utara dan menentang pembentukan Federasi Malaysia.

Presiden Sukarno sangat mendukung kemerdekaan NKKU. Hal ini dapat diketahu dari pidato-pidato Presiden Sukarno selaku Panglima Komando Tertinggi yang menyatakan bahwa peristiwa di Kalimantan Utara tidak bisa dilepaskan dari "The New Emerging Forces", sehingga Pemerintah Indonesia mendukung sepenuhnya kemerdekaan tersebut. Pembentukan Federasi Malaysia ini telah

\footnotetext{
31 "Revolusi Kemerdekaan di Kalimantan Utara", Kedaulatan Rakjat, 11 Desember 1962, hlm. 1.

${ }^{32}$ G. Dwipayana dan Ramadhan K.H, Soeharto, Pikiran Ucapan dan Tindakan Saya, (Jakarta: Citra Lamtoro Gunung Persada, 1989) hlm. 112.
} 
melahirkan pembrontakan yang dilakukan oleh Kelompok Azahari dengan mendirikan NKKU. ${ }^{33}$ Disamping itu penolakan-penolakan itu, datang juga peolakan dar Filiphina.

Untuk menghindari perang total, berbagai pihak dunia internasional melakukan upaya damai dengan mengajak kedua negara kemeja perundingan. Salah satu perundingan yang dilakukan terjadi pada tanggal 31 Mei 1963 di Tokyo, Jepang. Pertemuan antara Presiden Sukarno dengan PM Tengku Abdul Rahman akhirnya membuahkan sedikit harapan akan dicapainya perdamaian, karena kedua Negara setuju untuk kembali kepada The Spirit of The Malayan Indonesian Treaty of Frendship yang untuk sementara mengakhir ketegangan. Hasil perundingan ini membuat kedua belah pihak untuk melanjutkan perundingan-perundingan bilateral yang lain. ${ }^{34}$

Pada tanggal 7-11 Juni 1963, diadakan pertemuan lanjutan yang diadakan di Manila, Filiphina. Pertemuan ini dilakukan oleh para Menteri Luar negeri ini diikuti oleh perwakilan Indonesia (Subandrio), Malaya (Tun Abdul Razak) dan Filiphina (Emmanuel Pelaez). Hasil dari pertemuan di Manila menegaskan bahwa Indonesia dan Filiphina tidak keberatan dengan pembentukan Federasi Malaysia, asalkan dengan syarat, yaitu dengan dasar kemauan sendiri (self determination) bagi rakyat di wilayah-wilayah yang hendak digabungkan, dan ditentukan oleh otoritas yang bebas dan tidak memihak, yaitu Sekertaris Jendral PBB. Pertemuan ini kemudian diperkuat dengan sebuah Konferensi Tingkat Tinggi (KTT) antara PM Tengku Abdul Rahman, Presiden Macapagal dan Presiden Sukarno yang diadakan di Filiphina pada tanggal 31 Juli sampai 5 Agustus 1963. ${ }^{35}$

Kali ini KTT langsung dihadiri oleh para pemimpin negara. Presiden Sukarno dari Indonesia, PM Tengku Abdul Rahman dari Persekutuan Tanah Melayu, dan Presiden Macapagal dari Philipina. Pertemuan ini merupakan kelanjutan dari pertemuan sebelumnya. Dalam pertemuan ini dibahas

\footnotetext{
33 "Kita Tidak Mengclaim kal. Utara Hanja Simpata Atas Perdjuangan Rakjat Brunei”, Kedaulatan Rakjat, 26 Desember 1962.

${ }^{34}$ Nyoman Arsana, dkk, op.cit, hlm 27.

35 M.C.Ricklefs, Sejarah Indonesia Modern, (Jakarta: Serambi Ilmu Semesta, 2008) hlm. 583.

${ }^{36}$ Indonesia dan Filipina Sepakat Mengenai Empat Pasal, Sekitar Mafilindo dan Sengketa Malaysia", Kedaulatan Rakjat, 10 Januari 1964.

${ }^{37}$ Komisi yang dibentuk oleh Inggris dan Malaya untuk memungut dan menentukan pandangan rakyat Sabah dan
}

mengenai usulan Presiden Macapagal untuk membentuk federasi tiga Negara Rumpun Melayu dengan nama MAPHILINDO, dari kata Malaya, Philiphina dan Indonesia. Usul ini disambut baik oleh semua pihak yang berunding, bahkan PM Tengku Abdul Rahman menyatakan bersedia untuk menangguhkan proklamsi Federasi Malaysia yang akan dijadwalkan pada atanggal 31 Agustus 1963. PM Tengku Abdul Rahman juga mau menunggu hasil penyelidikan yang diselenggarakan oleh PBB tentang pendapat rakyat Kalimantan Utara mengenai pembentukan Federasi Malaysia ini. ${ }^{36}$

Agar tercapainya gagasan MAPHILINDO tersebut, maka ketiga Negara harus mematuhi hasil perundingan yang dikenal dengan Deklarasi Manila ini. Dalam KTT Manila ini, diperoleh beberapa hasil untuk menjadi solusi bagi masalah pembentukan Federasi Malaysia ini, salah satu poin terbesarnya mengatakan bahwa Malaysia tidak akan dibentuk sebelum hak untuk menentukan nasib sendiri dari rakyat Sabah dan Sarawak dilaksanakan. PBB mengambil tindakan baru dalam menentukan penentuan hak self determination yang sesuai dengan resolusi PBB 1541 pasal 9, hasil dari pemilihan yang sudah diadakan oleh Inggris melalui Komisi Cobbold. ${ }^{37}$

Sekjend PBB memilih 8 (delapan) anggota sekertariat untuk menjadi anggota dalam misi PBB menyelesaikan permasalahan mengenai pembentukan Federasi Malaysia ini. Tim ini diketuai oleh Lawrance Michelmore dari Amerika Serikat dan dibantu oleh 7 anggota yang berasal dari berbagai negara. Menurut Lawrance, semua penduduk Sabah dan Sarawak yang mengungsi diluar wilayah Kalimantan Utara harus diberikan hak untuk mengeluarkan suara dalam penentuan self determination ini. ${ }^{38}$ Sedangkan untuk negara-negara seperti Indonesia, Malaya dan Filiphina diperbolehkan mengirim peninjau-peninjau ke Kalimantan Utara pada saat berjalannya pengambilan hak suarat tersebut. Namun, banyak kejanggalan terjadi, seperti tim-tim dari Indonesia dan

Sarawak tentang pembentukan Federasi Malaysia. Lihat Sukarno, Dibawah Bendera Revolusi, (Jakarta: Pabitia Penerbit Dibawah Bendera Revolusi, 1965) hlm. 551.

${ }^{38}$ Banyak dari rakyat Kalimantan Utara yang mengungsi ke Kalimantan Indonesia, hal ini diakibatkan tekanan-tekanan yang diberikan oleh pihak militer Inggris di Sabah dan Sarawak. Menurut keterangan Pangdam XII/Tanjungn Pura, Kolonel Sudarsono, sampai bulan Juni 1963 tercatat 6.000 orang lebih mengungsi dan ditampung didaerah Kalimantan wilayah Indonesia. Lihat Nyoman Arsana, dkk. 2014. Op.cit. hlm 47. 
Filiphina dipersulit oleh pihak Inggris untuk menuju kedaerah pemungutan suata tersebut. Akibatnya, para peninjau tidak dapat menyelesaikan jalannya seluruh penyelidikan, dan hanya sepertiga dari pekerjaan pengawasan misi PBB ini bisa dijalankan. ${ }^{39}$

Ditengah proses menyelesaikan self determination rakyat Sabah dan Sarawak, PM Tengku Abdul Rahman dan Inggris mengumumkan mengengai Malaysia Day atau deklarasi kemerdekaan dan pembentukan Federasi Malaysia pada tanggal 16 September 1963, sedangkan tim PBB yang sedang menjalankan tugasnya belum selesai. Keputusan ini membuat kecewa berbagai pihak, termasuk Indonesia. Indonesia menganggap hal ini sebagai pelanggaran atas martabat PBB dan juga sebagai pengkhianatan atas pernyataan bersama dalam Deklarasi Manila. Menurut Presiden Sukarno, Indonesia telah "dikentuti". ${ }^{40}$ Pada Deklarasi Manila, secara tegas menegaskan bahwa penyeledikian kehendak rakyat Sabah dan Sarawak haruslah terlebih dulu dilaksankan sampai selesai menghasilkan laporan sebelum Federasi Malaysia diproklamirkan. Dan itu dilanggar oleh PM Tengku Abdul Rahman.

Peristiwa ini dianggap bukti bahwa PM Tengku Abdul Rahman maupun Inggris tidaklah jujur dan pemerintah Indonesia semakin gencar untuk menghancurkan proyek Federasi Malaysia tersebut. Pemerintah Indonesia mengajukan protes keras terhadap sikap PM Tengku Abdul Rahman itu. Reaksi Indonesia sangat keras terhadap sikap PM Tengku Abdul Rahman tersebut, yaitu memutuskan hubungan diplomatik dengan Malaya dan Singapura pada tanggal 17 September 1963. Meskipun hubungan diplomatik dengan Malaya ini menyangkut hampir separuh dari ekspor Indonesia.

Sengketa dengan Malaysia ini lebih meningkat lagi setelah panitia PBB yang diketuai oleh Michelmore dalam melakukan pemeriksaan tidak sesuai dengan tugasnya seperti tercantum dalam syarat-syarat yang ditentukan dalam persetujuan di Manila. Baik Indonesia maupun Philipina berbendapat bahwa

\footnotetext{
${ }^{39}$ Marwati Djoned Poesponegoro, dkk. Sejarah Nasional Indonesia VI, (Jakarta: Balai Pustaka. 2012) hlm. 357.

${ }^{40}$ G. Dwipayana dan Ramadhan K.H, Soeharto, Pikiran Ucapan dan Tindakan Saya, (Jakarta: Citra Lamtoro Gunung Persada, 1989) hlm. 112.

41 "Adakan Gerakan Sukarelawan! Tjatur Tunggal dan Front Nasional = pantja Tunggal", Kedaulatan Rakjat, 17 Maret 1964.
}

Panitia Michelmore tidak melakukan pemeriksaan secara demokratis. Dengan adanya anggapan itu, Pemerintahan Indonesia tidak bersedia mengakui Malaysia dan membuka tahap baru konfrontasi dengan Malayisa dengan semangat Ganyang Malaysia.

Bersama dengan seruan itu, kegiatan militer ditingkatkan, pasukan dan relawan dipersiapkan. Kegiatan gerilyawan dilancarkan dari Kalimantan, wilayah yang secara teritorial berbatasan langsung dengan Sabah dan Sarawak. Patroli-patroli ditingkatkan, seperti patroli diperbatasan Selat Malaka dan perbatasan Singapura. Kebijakan politik "Ganyang Malaysia" ini menggoncang kestabilan keamanan dan menimbulkan ketegangan diwilayah Asia Tenggara.

Presiden Sukarno mengumandangkan sebuah gerakan untuk para sukarelawan pada saat Konfrensi Presidium Kabinet dengan Catur Tunggal dan Front Nasion kepada seluruh rakyat Indonesia yang diselenggarakan di Jakarta pada tanggal 11-16 Maret $1964 .{ }^{41}$ Presiden Sukarno memberikan pidato saat penutupan Konfrensi Presidium Kabinet Kerja, beliau mengatakan bahwa,

"Abdul Rahman mengadakan satu mobilisasi. Apa djawab saja? Apa komando saja? Bukan sekedar kepada TjaturTunggal, tetapi kepada seluruh Rakjat Indonesia, djawab saja ialah: Okay, djikalau Abdul Rahman tidak mau musjawarah dengan kami, okay! Djikalau Abdul Rahman mengadakan mobilisasi umum, okey! Saja Komandokan Sekarang Satu Gerakan Sukarelawan Indonesia". ${ }^{42}$

Pada saat pidatonya, di Apel Besar Sukarelawan Pengganyangan Malaysia di depan Istana Merdeka pada 3 Mei 1964, Presiden Sukarno mengatakan "Malaysia adalah bahaja, mebahajai, membahajakan Revolusi Indonesia. Karena itu maka kita serempak seia-sekata, Malaysia harus kita ganjang habis-habisan". ${ }^{43}$ Pada saat apel tersebut, Presiden Sukarno mengumandangkan pidato Dwikora (Dwi Komando Rakyat) dihadapat 21 juta

\footnotetext{
42 Departemen Penerangan RI, Gelora Konfrontasi Mengganjang "Malaysia", (Jakarta: Departemen Penerangan RI, 1964) hlm. 277.

43 Amanat-komando Presiden/Pangliam Tertinggi/ Pemimpin Besar Revolusi Indonesia pada Appel Besar Sukarelawan Pengganjangan Malaysia Didepan Istana Merdeka, Djakarta 3 Mei 1964. Arsip Nasional Republik Indonesia. hlm. 2.
} 
sukarelawan, yang berisi, "Perhebat Ketahanan Revolusi Indonesia dan Bantu Perjuangan Revolusioner Rakyat-Rakyat Malaya, Singapura, Sabah, Sarawak dan Brunei untuk Membubarkan Negara Boneka Malaysia". ${ }^{4}$

Presiden Soekarno menjelaskan maksud utama Dwikora sebenarnya bukan bermusuhan dengan serumpun bangsa Melayu, melainkan untuk mengusir Inggris (Imperialisme/ Kolonialisme) dari wilayah Asia oleh bangsa Melayu sendiri dan membangkitkan semangat nasionalisme, militansi dan patriotisme untuk mengusir Inggris. Seruan itu diperkuat dengan Keputusan Presiden (Keppres) No. 95 tahun 1964, tentang pengerahan sukarelawan Indonesia dalam rangka peng-ganyang-an dan penghancuran proyek Neo-kolonialisme Malaysia. Pada saat itu, jiwa patriotisme warga negara Indonesia ikut terpanggil untuk membela harkat martabat bangsa, sehingga banyak para sukarelawan yang mendaftar dan diberangkatkan kedaerah persiapan di sekitar Kepulauan Riau dan Kalimantan.

\section{Kontribusi dalam Konfrontasi}

Dalam mendukung Operasi Dwikora ini ikut serta dalam Operasi A/KOTI (operasi interiterritorial, impact politis, sabotase dan lainnya), yang langsung dibawah Men/Pangad. Daerah-daerah disektar Riau merupakan basis dari kesatuan Ops.A/KOTI sejak tahun 1964. Antara Detasemen Tugas dengan Ops.A/KOTI saling melakukan kordinasi yang sangat baik, misalnya melindungi infiltrasi Ops.A/KOTI yang berangkat dan pulang dari daerah lawan. Pasukan-pasukan yang ikut dalam operasi ini berstatus sebagai sukarelawan, termasuk pasukan KKO-AL.

Untuk menghadapi kondisi medan di sekitar daerah perbatasan laut, seperti Selat Malaka dan Kepulauan Riau. Maka dilakukan Operasi A/KOTI yang berada di bawah Menteri/Panglima Angkatan Darat (Men/Pangad). Kesatuan Operasi A/KOTI menjadikan wilayah Kepulauan Riau sebagai basisnya sejak akhir tahun 1963. Sebagai salah satu pasukan berkualifikasi khusus, KKO-AL secara simultan melaksanakan seranngkaian latihan operasi yang bersifat khusus pula seperti infiltrasi, demolisi, sabotase, gerilya, serta operasi intilijen dan perang hutan. Latihan infiltrasi, gerilya dan perang hutan menjadi fokus utama mengingat kondisi medan Kalimantan sebagian besar berupa bukit-bukit berlembah yang diselimuti hutan rimba lebat. Sementara untuk menghadapi medan operasi disekitar Selat Malaka, KKO-AL menambahkan latihannya dengan materi renang tempur, infiltrasi dan sabotase melalui laut.

KKO-AL merekrut anggota militer maupun sipil sebagai sukarelawan. Guna menjaring anggota yang akan dijadikan prajuritprajurit yang memenuhi standar tersebut, KKOAL melaksanakan serangkaian seleksi personel. Janatin, yang pangkatnya telah dinaikkan menjadi Prajurit II KKO setelah bertugas di Irian Barat, berhasil lulus seleksi dan mengikuti latihan khusus di Cisarua, Bogor. Latihan ini dilakukan selama satu bulan pada bulan April 1964. Adapun materi pendidikan meliputi intelijen dan kontraintelijen, sabotase, demolisi, gerilya, dan sebagainya. Pelatihan khusus ini dikomandani Mayor KKO-AL Budi Prayitno dan Letnan KKO-AL Harahap sebagai wakilnya. Selama mengikuti pendidikan khusus ini, para calon sukarelawan dibagi dalam 13 tim, yang setiap tim terdiri dari 20-25 orang.

Proses rekrutmen sukarelawan juga dilaksanakan di kesatuan-kesatuan ABRI lainnya dan diperkirakan lebih dari 21 juta warga negara Indonesia bergabung. Salah seorang sukarelawan yang bergabung dengan KKO-AL adalah Tohir bin Mahdar. Untuk meningkatkan kemampuannya, Tohir dan calon sukarelawansukarelawan lainnya mengikuti pendidikan dan pelatihan kemiliteran selama 5 bulan di daerah Riau daratan. Tohir nantinya akan menjadi rekan Janatin dalam menjalankan tugasnya di Singapura. Siapa Tohir?

Tohir alias Harun bernama ali Tohir dilahirkan tanggal 4 April 1943 di Pulau Bawean, sebuah pulau kecil yang berjarak $15 \mathrm{~km}$ arah Utara Kota Surabaya. Ia merupakan anak ketiga dari pasangan Mundah dan Aswiyani. Tohir dibesarkan dilingkungan masyarakat maritim dan sejak kecil kerap berlayar dengan kapal nelayan atau kapal dagang keberbagai daerah. Sejak masa SMP, ia selain sekolah juga bekerja sebagai awak kapal dan yang sering mengadakan perjalanan keluar negeri. Termasuk sering berlabuh di Pelabuhan Sinapura.

\footnotetext{
${ }^{44}$ C.S.T. Kansil dan Julianto. op. cit. hlm. 81.
} 
Makanya tak heran ia sangat tahu seluk beluk wilayah Singapura. ${ }^{45}$

Guna memperkuat Operasi A/KOTI, KKO-AL mengerahkan sekitar 300 personel mulai dari pangkat perwira hingga kopral. Kesatuan-kesatuan yang tergabung dalam Operasi A/KOTI selanjutnya dibagi menjadi beberapa tim dengan "Sandi Brahma" dan berada dibawah kendali dua basis. Basis II bertugas mengkoordinasikan operasi di Semenanjung Malaya dan Basis VI bertugas di wilayah Kalimantan Utara. Janatin menerima tugas berdasar dengan SP. KKO No. 05/SP/KKO/64 dan Spd. KOTI No. 288/KOTI/8/64 tertanggal 27 Agustus 1964. Janatin ditugaskan untuk melakukan tugas kewilayah Basis II dengan Sub-Basis X di Pulau Sambu. ${ }^{46}$ Dengan menggunakan kapal Meriam (gunboat), Janatin dan kawan-kawan langsung menuju ke Pulau Sambu untuk menggabungkan diri dengan sukarelawan lainnya dalam Tim Brahma I. Tim Brahmana I ini dibawah pimpinan Kapten KKO-AL Paulus Subekti. Di Pulau Sambu inilah Janatin berjumpa dengan Tohir dan seorang Sukarelawan bernama Gani. ${ }^{47}$

Janatin, Tohir dan Gani yang untuk selanjutnya ditempatkan di Pulau Layang guna menyipakan diri melaksanakan tugas. Saat itu, Kapten KKO-AL Paulus Subekti menyamar dengan pangkat Letnan Kolonel KKO dan merangkap sebagai Komandan Sub-basis X. Janatin, Tohir, dan Gani mendapat tugas yang sama yakni melakukan infiltrasi sekaligus mengadakan sabotase di instalasi militer Inggris di Singapura.

Saat memperoleh perintah untuk melaksanakan infiltrasi dan kegiatan intelijen ke wilayah Singapura, Janatin ditunjuk sebagai Komandan Tim. Penunjukan Janatin menjadi ketua rim dikarenakan lebih senior dan memiliki pengalaman kemiliteran yang lebih dibandingkan rekan lainnya. Namun kelemahannya, Janatin "buta" dengan situasi Singapura. Tohir, justru sebaliknya, sangat paham dengan situasi Singapura, bahkan hafal gang-gang kecilnya. Oleh sebab itu, Janatin

\footnotetext{
45 Kuncoro Hadi dan Sustianingsih, Buku Pintar Super Lengkap Pahlawan Nasional, (Yogyakarta: Familia, 2015), hlm 116.

${ }^{46}$ Muchtaruddin Ibrahim. Usman Bin Haji Muhamad Ali alias Jantin, (Jakarta: Proyek Inventarisasi dan Dokumentasi Sejarah Nasional, 1993), hlm. 29.

47 Gani Bin Raop tidak terlalu banyak sumber mengenainya, hanya ia merupakan sukarelawan dari
}

banyak memperoleh informasi mengenai Singapura dari Tohir.

Bukan perkara mudah menyusup ke wilayah Singapura, yang dijaga demikian ketat baik darat maupun laut. Guna mengelabui agenagen rahasia atau informan Inggris dan Malaysia, Janatin mengganti namanya menjadi nama yang familir di daerah tersebut, yaitu Usman bin Haji Muhammad Ali. Mereka menyamar sebagai pedagang yang kerap hilir mudik dengan menggunakan perahu kecil. Dengan berkedok pedagang keliling, ketiganya banyak mendapatkan keterangan serta leluasa melakukan pengintaian dibeberapa objek vital. Ketiganya berhasil masuk ke Singapura dan kembali ke basis dengan selamat sebanyak dua kali. Penyamaran ini membawa informasi penting untuk dilakukan tindakan selanjutnya. Di basis Pulau Sambu inilah, didiskusikan bebrapa titik sasaran beserta kemungkinan dan dampak yang bisa ditimbulkan.

Pada tengah malam 8 Maret 1965, mereka mendapat perintah untuk kembali menyusup dan melakukan aksi sabotase terhadap instalasi militer atau kepentingan-kepentingan Inggris di Singapura. Oleh sebab itu, mereka dibekali bahan peledak seberat 12,5 kilogram. ${ }^{48}$ Mereka memilih tempat untuk meletakan bom itu, dari hasil penyelidikan, mereka bertiga sepakat untuk melakukan peledakan gedung megah yang terletak di pusat Orchard Road dan tidak jauh dari Istana Kepresidenan Singapura, yaitu MacDonald House. ${ }^{49}$

Tepat pukul 03.07 malam bertepatan dengan tanggal 10 Maret 1965, terdengan suara bom meledak. Setelah suasana ledakan bom terjadi, suasana riuh menyelimuti MacDonald House karena diselimuti kepanikan. Ledakan tersebut mengakibatkan 6 orang meninggal dan 35 terluka, sementara Singapura mengklaim meninggal 3 orang dan 33 terluka. Janatin, Tohir, dan Gani berhasil menyelinap keluar di antara kepanikan penghuni MDH yang berhamburan ke luar gedung. Untuk sementara, tugas mereka mendapatkan kesuksesan besar.

Esok harinya, tanggal 11 Maret 1965, Janatin, Tohir, dan Gani bertemu sekaligus

kalangan sipil yang lolos menjadi sukarelawan, kemudian bergabung dengan Janatin dan Tohir.

48 Mabes TNI. Biografi Pahlawan Nasional dari Lingkungan TNI. (Jakarta: Markas Besar Tentara Nasional Indonesia, Pusat Sejarah, 2014), hlm 425.

${ }^{49}$ Murgiyanto. Usman dan Harun Prajurit Setia. Jakarta: Direktoat Perawatan Personil TNI-AL. 1989. hlm. 12. 
merundingkan kemungkinan cara kembali ke basis secepatnya. Namun pada saat yang sama petugas keamanan dan kepolisian Singapura menggelar serangkaian operasi pencarian besarbesaran. Berbeda dengan saat mereka masuk, kali ini penjagaan sangat ketat dan aturan keras diberlakukan. ${ }^{50}$ Sebenarnya mereka akan melakukan peledakan lanjutan pada sebuah aperteman yang tidak jauh dari Hotel Mc Donald, namun karena bahan peledak yang mereka bawa sudah habis akhirnya mereka sepakat untuk kembali ke pangkalan sekaligus melaporkan apa yang telah berhasil mereka lakukan.

Pada hari itu juga mereka berpisah, karena tidak memungkinkan untuk bertiga. Sedangkan Janatin dan Tohir tetap bersama meskipun tidak berdekatan guna menghindari kecurigaan petugas keamanan Singapura, sedangkan Gani sudah menghilang entah kemana. Janatin dan Tohir menggunakan cara dengan menujukan kartu anggota PRM (Pasific Richfield Marine) Singapura dan menyamar sebagai aggota awak kapal dagang yang sedang singgap dipelabuhan. Tohir yang banyak mengenal Singapura berhasil mengelabui petugas kepolisian dan bersama Janatin menyamar sebagai pelayan dapur di Kapal dagang Begama yang hendak berlayar menuju Bangkok, Thailand. Saat menaiki kapal Begema ini, mereka menyamar menjadi pelayan dapur. Mereka berhasil bersembunyi dengan aman dikapal itu sampai tanggal 12 Maret $1965 .{ }^{51}$ Hingga kejadian tak terduga menimpa mereka, pada malam harinya pemilik kapal Begema, Kie Hok menyadari akan keberadaan mereka dan langsung mengusir keduanya untuk keluar dari kapal.

Pada pagi hari, Janatin dan Tohir meninggalkan kapal tersebut, kemudian mereka berusaha mencari kapal untuk meninggalkan Singapura dan kembali kepangkalan. Ketika merka sedang mencari, tiba-tiba datang sebuah motor boat. Motor itu dikendarai oleh orang Tionghoa. Mereka harus memilih, pasrah dan menyerah atau berbuat sesuatu dengan dua kemungkinan, yaitu tertangkap atau lolos. Akhirnya dengan kebulatan tekad mereka berhasil merebut motor boat tersebut yang

\footnotetext{
${ }^{50}$ Muchtaruddin Ibrahim. op. cit. hlm. 32.

${ }^{51}$ Ibid,. hlm. 35.

${ }^{52}$ Herman Mujirun. op. cit. hlm. 3.

53 Pasukan-pasukan itu merupakan pasukan yang prokomunis. Mereka adalah para sukarelawan yang dilatih oleh Indonesia sendiri. Saat itu mereka tidak terima terhadap kebijakan Presiden Soeharto yang menghentikan
}

digunakan untuk menyeberang menuju ke Pulau Sambu.

Dalam pelayaran yang penuh ketegangan, mereka bernasib malang karena sebelum berhasil menyeberangi perairan perbatasan Indonesia-Singapura, mesin motor boat mereka macet dan mengalami gangguan. Ketika mereka sedang memperbaiki motor boat yang rusak, keberadaan mereka berhasil diketahui oleh polisi perairan Singapura. Mereka tidak dapat menghindar lagi, sehingga pada pukul 09.00 tanggal 13 Maret 1965 mereka ditangkap dan ditahan oleh kepolisian Singapura. ${ }^{52}$ Tertangkapnya mereka membuat petualangan terhenti.

Dengan proses peradilan yang panjaang, akhirnya keduanya dijatuhi hukuman mati dengan cara digantung yang akan dilaksanakan pada 17 Oktober 1968. Bantuan oleh pemerintah Indonesia dengan berbagai cara tak bisa menyelamatkan keduanya. Pada hari eksekusi, Presiden Soeharto sedang berada di Pontianak menunjau daerah Kalimantan Barat yang masih mendapat gangguan dari gerombolan Pasukan Gerilya Rakyat Serawak (PGRS) dan Pasukan Rakyat Kalimantan Utara (PARAKU). ${ }^{53}$ Sewaktu Presiden Soeharto diberitahukan bahwa Pemeritnah Singapura telah melaksanakan hukuman gantung terhadan Janatin dan Tohir, maka Presiden Soeharto menyatkan kedua prajurit KKO-AL itu sebagai Pahlawan Nasional secara lisan. Keesokan harinya untuk menghormati dan menghargai perjuangan salah satu putra terbaik bangsa, dan sesuai dengan janji dari Presiden Soeharto untuk mengangkat mereka sebagai Pahlawan Nasional. Janji itu dikukuhkan berdasarkan Keputusan Presiden RI No. 050/TK/1968 tertanggal 17 Oktober 1968 telah memberikan pangkat satu tingkat atau mengangkat Serda KKO (Anm) Usman dan Kopral KKO (Anm) Harun sebagai Pahlawan Nasional. $^{54}$ 


\section{PENUTUP}

\section{Simpulan}

Usman Janatin merupakan Pahlawan Nasional dengan SK Presiden RI No. 050/TK/1968 tertanggal 17 Oktober 1968. Dengan jiwa patriotnya, ia rela mengorbankan nyawanya demi membela harkat dan martabat bangsa. Cita-citanya membela negara terwujud, sesuatu yang dicita-citakan dari kecil. Sosok ini berperan dalam peristiwa "panas" yang mewarnai hubungan Indonesia dan Malaysia. Konfrontasi ini memanggil seluruh segenap warga Indonesia untuk membela martabat bangsanya, Usman Janatin merupakan salah satu warga Negara yang terpanggil. Sebagai anggota KKO-AL, Ia berhasil melaksankana tugasnya untuk melakukan sabotase dengan meledakan salah satu gedung Hotel Mc Donald. Bersama rekanya, Tohir alias Harun bin Said dan Gani bin Raop, mereka berhasil melaksanakna tugasnya dengan baik. Meskipun nasib mereka berakhir ditiang gantungan, namun keteladanannya patut menjadi renungan bagi generasi masa kini.

\section{DAFTAR PUSTAKA}

"Adakan Gerakan Sukarelawan! Tjatur Tunggal dan Front Nasional = pantja Tunggal", Kedaulatan Rakjat, 17 Maret 1964.

Adrian Vickers. 2005. A History of Modern Indonesia. New York. Cambridge University Press.

Anwar Yasin. 1987. Pembaharuan Kurikulum Sekolah Dasar, Sejak Proklamasi Kemerdekaan. Jakarta: Balai Pustaka.

Cribb. Robert dan Kahin, Audrey. 2004. Historical Dictionary of Indonesia. Toronto: The Scarecrow Press, Inc.

C.S.T. Kansil \& Julianto. 1972. Sedjarah Perdjuangan Pergerakan Kebangsaan Indonesia. Jakarta: Erlangga.

Departemen Penerangan RI. 1964. Gelora Konfrontasi Mengganjang "Malaysia". Departemen Penerangan Republik Indonesia.

Dhakidae, Daniel. 2014. "Hubungan CintaBenci antara Indonesia dan Malaysia". Majalah Prisma Vol. 28, No. 2, September 2009, hal 50-53.

Dwipayana,dkk. 1989. Soeharto, Pikiran Ucapan dan Tindakan Saya. Jakarta: Citra Lamtoro Gunung Persada.
Frans. S. Fernandes. 1988. Hubungan Internasional dan Peranan Bangsa Indonesia: Suatu Pendekatan Sejarah. Jakarta: Departemen Pendidikan Dan Kebudayaan Direktorat Jendral Pendidikan Tinggi Proyek Pengembangan Lembaga Pendidikan Tenaga Kependidikan.

Farram, Steven. 2014. "Ganyang! Indonesian Populer Songs from the Confrontation Era, 1963-1966". Jurnal Bijdragen Tot De Tall-, land-En Volkenkunde 170 (2014) 124.

Gamal Komandoko. 2008. 125 Pahlawan dan Pejuang Nusantara. Jakarta: Pustaka Widya.

Herman Mujirun. 1974. Sekilas Kenangan 2(dua) Pahlawan Serda KKO Bin H.Ali dan Kopral KKO Harun Bin Said. Jakarta: Yayasan Sosial Usman-Harun.

Imam Tholhah. 2001. Anatomi Konflik Politik di Indonesia: Belajar dari Ketegangan Politik Varian di Madukoro,. Jakarta: PT. Raja Grafindo Persada.

Ibrahim, Muchtaruddin. 1993. Usman Bin Haji Muhammad Ali alias Janatin. Jakarta: Proyek Inventarisasi dan Dokumentasi Sejarah Nasional.

"Kita Tidak Mengclaim kal. Utara Hanja Simpata Atas Perdjuangan Rakjat Brunei”, Kedaulatan Rakjat, 26 Desember 1962.

Kuntowijoyo. 1995. Pengantar Ilmu Sejarah. Yogyakarta: Yayasan Bentang Budaya

Koentjaraningrat. 1994. Kebudayaan Jawa. Jakarta: Balai Pustaka.

Kuncoro Hadi dan Sustianingsih. 2015. Buku Pintar Super Lengkap Pahlawan Nasional. Yogyakarta: Familia.

Kusumah Hadiningrat. 1971. Sedjarah OperasiOperasi gabungan Dalam Rangka Dwikora, Jakarta: Departeman Pertahanan - Keamanan Pusat Sedjarah ABRI.

Loanglois, CH.V dan Seignobos, CH. 2015. Introduction to the Study of Hostory, Pengantar Ilmu Sejarah (terj). Yogyakarta: Indoliterasi.

Muhaimin, Yahya A. 2005. Perkembangan Militer dalam Politik di Indonesia 19451966 (certakan ke-tiga). Yogyakarta: Gadjah Mada University Press.

Murgiyanto. 1989. Usman dan Harun Prajurit Setia. Jakarta: Direktorat Perawatan Personil TNI-AL Subdit Sejarah. 
M.C. Ricklefs. 2005. Sejarah Indonesia Modern 1200-2004. Jakarta: Serambi.

------. 2008. Sejarah Indonesia Modern. Jakarta: Serambi Ilmu Semesta.

Marwati Djoened Poesponegoro\&Nugroho Notosusanto. 1993. Sejarah Nasional Indonesia VI. Jakarta: Balai Pustaka.

Majalah Marinir, "Sejarah Korps Marinir dan Emblem", edisi 144, November 2014, hlm. 4.

Mahpudi, et.al. 2014. Pak Harto, The Untold Sories. Jakarta: Kompas Gramedia.

Mohd Noor bin Abdullah. 1979. Kemasukan Sabah dan Serawak ke dalam Persekutuan Malaysia. Kuala Lumpur: Dewan Bahasa dan Pustaka Kementrian Pelajaran Malaysia.

Mabes TNI. 2014. Biografi Pahlawan Nasional dari Lingkungan TNI. Jakarta: Markas Besar Tentara Nasional Indonesia, Pusat Sejarah.

Nyoman Arsana, dkk. 2014. Operasi Dwikora, 1962-1966. Jakarta: Tapasuma Ratu Agung.

Petikan Keputusan Presiden Republik Indonesia No. : 050/TK/Tahun 1968 Tentang Penganugerahan Gelar Pahlawan Dan Tanda-Kehormatan Bintang Sakti.

Priyadi, Sugeng. 2011. Metode Penelitian Sejarah. Yogyakarta: Pustaka Pelajar.

"Revolusi Kemerdekaan di Kalimantan Utara", Kedaulatan Rakjat, 11 Desember 1962, hlm. 1.

Roso Daras. 2013. Total Bung Karno, Serpihan Sejarah yang Tercecer (cetakan keempat). Depok: Penerbit Imania

Sasono dan Tri Atmo. 1993. Mengenal Purbalingga. Jakarta: Paguyuban Arsantaka.

Shahab, Alwi. 2014. "Usman-Harun dan Ekspresi Kemarahan Rakyat". Koran Republika, 13 Februari 2014, halaman 1 dan 9.

Shuib, Shukri, Md. et al. 2009. "The Implications of Cold War on Malaysia State Building Process". Jurnal Asian Culture and History, Vol 1, No. 2, July 2009, hlm 89-98.

Sukarno. 1965. Dibawah Bendera Revolusi. Jakarta: Pabitia Penerbit Dibawah Bendera Revolusi.

Sukardi, Tanto. 2011. Perang Dingin: Episode Sejarah Barat dalam Perspektif Konflik Ideologi. Yogyakarta: Pustaka Pelajar.
Suko Bandiyono, dkk. 2004. Mobilitas Penduduk di Perbatasan Papua-PNG. Jakarta: Pusat Penelitian Kependudukan Lembaga Ilmu Pengetahuan Indonesia (PPK-LIPI).

Wawancara dengan Siti Rodijah, kakak kandung Janatin, tanggal 17 Juli 2017 dirumahnya Desa Jatisaba, Kabupaten Purbalingga.

Wawancar dengan Ahmad Matori, kakak kandung Janatin, tanggal 26 Juli 2017 dirumahnya Desa Jatisaba, Kabupaten Purbalingga.

Wawancara dengan Siti Turijah, adik kandung Janatin, tanggal 28 Juli 2017 di rumahnya Desa Jatisaba Purbalingga.

Wawancara dengan Pak Artijo, teman kecil dan adik ipar Janatin, tanggal 28 Juli 2017 di rumahnya Desa Jatisaba Purbalingga. 